\title{
Upaya Meningkatkan Kemampuan Menulis Cerita Fantasi Dengan Menggunakan Metode Picture And Picture Pada Siswa Kelas VII A SMPN 2 Sindangresmi
}

\author{
Asri Hayati Futri, Eman Supriatna \\ STKIP Mutiara Banten \\ Email: $\underline{\text { emansprtn@gmail.com }}$
}

\begin{abstract}
Classroom Action Research is carried out with the aim to improve students' ability to write fantasy story text using the picture and picture method in learning. The study was conducted in class VII A, semester 1, 2019/2020 Academic Year, Sindangresmi State Middle School 2. This research is motivated by the low interest, activeness and ability of students in writing fantasy stories. This happens because of inaccurate selection of instructional media used by teachers. Learning media used by teachers are less varied and less interesting in learning to write fantasy stories so students feel bored. The problems examined in this study are (1) How can the use of picture and picture learning methods increase the interest of Grade VII A students of SMP Negeri 2 Sindangresmi in writing fantasy text? (2) How can the use of picture and picture learning methods increase the activeness of Grade VII A students of SMP Negeri 2 Sindangresmi in writing fantasy text? and (3) How to improve the ability to write fantasy stories using the picture and picture method in class VII A of SMP Negeri 2 Sindangresmi? Classroom Action Research is carried out in 2 cycles, each cycle consisting of 4 stages, namely planning, implementing, observing and reflecting. The instruments used in this study were in the form of learning outcomes test sheets given before the action (pre-action / pre-cycle) and after the action, observation sheets and group worksheets. Data collection and processing based on data obtained on these instruments. The ability to write fantasy stories in grade VII students of SMP Negeri 2 Sindangresmi increased after using the picture and picture method by 22.77 . The average in the first cycle showed an increase compared to the average in the pre-cycle of 60.23 to 71.5. The average achieved in the second cycle 83, this refers to an increase of 11.27 from pre-cycle to cycle I, 11.5 from cycle I to cycle II. Changes in students' activities and interests in learning to write fanntasi stories using the picture and picture method have experienced positive changes. The results showed that learning Indonesian basic competencies in writing fantasy text texts using the picture and picture method turned out to increase the activeness, interest, and learning outcomes of students in the form of the ability to write fantasy stories, compared with learning activities before conducting research. After conducting classroom action research using the picture and picture method there was an increase.
\end{abstract}

Keywords: Picture and Picture Method, activeness, interest, writing ability, grade VII A students of SMP Negeri 2 Sindangresmi.

\begin{abstract}
Abstrak. Penelitian Tindakan Kelas dilaksankan dengan tujuan untuk meningkatkan kemampuan siswa dalam menulis teks cerita fantasi dengan menggunakan metode picture and picture dalam pembelajaran. Penelitian dilaksankan di kelas VII A, semester 1, Tahun Pelajaran 2019/2020, SMP Negeri 2 Sindangresmi. Penelitian ini dilatar belakangi rendahnya minat, keaktifan serta kemampuan siswa dalam menulis cerita fantasi. Hal ini terjadi karena ketidak tepatan pemilihan media pembelajaran yang digunakan guru. Media pembelajaran yang digunakan oleh guru kurang bervariasi dan kurang menarik dalam pembelajaran menulis cerita fantasi sehingga siswa merasa bosa. Masalah yang dikaji dalam penelitian ini adalah (1) Bagaimana penggunaan metode pembelajaran picture and picture dapat meningkatkan minat siswa kelas VII A SMP Negeri 2 Sindangresmi dalam menulis teks cerita fantasi? (2) Bagaimana penggunaan metode pembelajaran picture and picture dapat meningkatkan keaktifan siswa kelas VII A SMP Negeri 2 Sindangresmi dalam menulis teks cerita fantasi? dan (3) Bagaimana meningkatkan kemampuan menulis cerita fantasi dengan menggunakan metode picture and picture pada siswa kelas VII A SMP Negeri 2 Sindangresmi? Penelitian Tindakan Kelas dilaksankan 2 siklus yang tiap siklusnya terdiri 4 tahap, yakni perencanaan, pelaksanaan, observasi dan refleksi. Inttrumen yang digunakan dalam penelitian ini berupa lembar tes hasil belajar yang diberikan sebelum tindakan (pratindakan/prasiklus) dan setelah tindakan, lembar observasi serta lembar kerja kelompok. Pengumpulan data dan penggolahannya berdasarkan data yang didapatkan pada intrumen tersebut. Kemampuan menulis cerita fantasi pada siswa kelas VII SMP Negeri 2 Sindangresmi meningkat setelah menggunakan metode picture and picture sebesar 22,77. Rata-rata pada siklus I menunjukan
\end{abstract}


peningkatan dibandingkan dengan rata-rata pada prasiklus 60,23 menjadi 71,5. Rata-rata yang dicapai pada siklus II 83 , ini menujukan peningkatan sebesar 11,27 dari prasiklus ke siklus I, 11,5 dari siklus I ke siklus II. Perubahan aktivitas dan minat siswa dalam pembelajaran menulis cerita fanntasi dengan menggunakan metode picture and picture telah mengalami perubahan kearah yang positif. Hasil penelitian menunjukkan bahwa pembelajaran Bahasa Indonesia kompetensi dasar menulis teks cerita fantasi dengan menggunakan metode picture and picture ternyata dapat meningkatkan keaktifan, minat, dan hasil belajar peserta didik dalam bentuk kemampuan menulis cerita fantasi, dibandingkan dengan kegiatan pembelajaran sebelum melakukan penelitian. Setelah diadakan penelitian tindakan kelas dengan menggunkan metode picture and picture ada peningkatan.

Kata Kunci : Metode Picture and Picture, keaktifan, minat, Kemampuan Menulis, siswa Kelas VII A SMP Negeri 2 Sindangresmi.

\section{A. PENDAHULUAN}

Bahasa merupakan alat komunikasi untuk menyampaikan gagasan, pikiran, maksud dan tujuan kepada orang lain. Bahasa memiliki peran yang sangat penting bagi kehidupan manusia. Dalam dunia pendidikan komunikasi sangat penting, agar dapat menyampaikan informasi yang tepat. keterampilan berbahasa merupakan sesuatu yang penting bagi setiap orang saling berhubungan dengan orang lain, dengan cara berkomunikasi. Ada empat keterampilan berbahasa yang harus di miliki setiap siswa sebagai hasil belajar. Keempat jenis keterampilan berbahasa meliputi keterampilan menyimak, berbicara, membaca dan menulis. Dalam keterampilan merupakan rangkaian kegiatan seseorang dalam menuangkan penyampaiannya melalui bahasa tulis kepada pembaca. (Dalman, 2018 : 2) Menulis merupakan suatu kegiatan komunikasi berupa penyamapaian pesan atau informasi secara tertulis kepada pihak lain dengan menggunakan bahasa tulis sebagai alat atau medianya. Aktivitas menulis melibatkan beberapa unsur yaitu : penulis sebagai penyampaian pesan, isi tulisan, saluran atau media, dan pembaca. (Dalman, $2018: 3$ )

Pada saat ini pembelajaran menulis lebih banyak disajikan dalam bentuk teori, tidak hanya melakukan peraktik menulis. Hal ini menyebabkan kurangnya kebiasaan menulis sehingga siswa sulit menuangkan idenya dalam bentuk tulisan. (Widiarti, $2013: 3$ )

Kurikulum 2013 merupakan pembelajaran berbasis teks untuk menunjang pembelajaran menulis siswa disekolah. Dalam buku bahasa Indonesia kelas VII revisi kurikulum 2013 pada tahun 2017 mengalami perubahan terutama pada lingkup materi. Berdasarkan silabus bahasa Indonesia tingkat SMP/MTS kelas VII terdapat jenis teks yang harus dipelajari dalam mata pelajaran bahasa Indonesia, yaitu : teks deskripsi, teks cerita fantasi, teks prosedur, teks laporan hasil observasi, puisi rakyat, cerita rakyat, surat dan literasi. (Permendikbud, 2016)

Berdasarkan revisi kurikulum 2013 cerita fantasi merupakan salah satu bentuk narasi di dalam pembalajaran bahasa Indonesia kelas VII semester 1 kurikulum 2013 pada kompetensi inti (KI) 4, yaitu mencoba, mengolah, dan menyaji dalam ranah konkret (menggunakan, mengurai, memodifikasi, membuat) dan ranah abstrak (menulis, membaca, menghitung, menggambar, dan mengarang) dengan Kompetensi Dasar (KD) 4.4 yaitu menyajikan gagasan kreatif dalam bentuk cerita fantasi secara lisan dan tulis dengan memperhatikan struktur dan bahasa. Dalam cerita fantasi terdapat keajaiban, keanehan, kemisteriusan, dan bersifat 
supranatural yang tidak dijumpai dalam dunia nyata. Dunia fantasi atau dunia khayal yang dimiliki siswa berbedabeda sesuai imajinasinya. Oleh karena itu, cerita fantasi dipilih guna meningkatkan daya imajinasinya yang dituangkan dalam tulisannya. (Harsiati, Titik dkk, $2016: 50$ ).

Berdasarkan hasil observasi yang dilakukan oleh peneliti di SMP Negeri 2 Sindangresmi menegenai kemampuan menulis siswa. Kemampuan menulis teks cerita fantasi siswa rendah yaitu 63,8\% (Daptar Nilai Kelas VII A dari Guru Bahasa Indonesia) karena, seringkali hanya beberapa siswa yang mendapatkan nilai Kriteria Ketuntasan Minimal (KKM) yaitu 75, hal tersebut dapat dilihat dari persentase ketuntasan dalam pembelajaran menulis teks cerita fantasi. 30 orang siswa kebanyakan mendapat nilai dari 50-70.

Berdasarkan hasil wawancara dengan guru bahasa Indonesia bahwa kemampuan menulis siswa masih rendah. Hal tersebut disebabkan : 1) siswa masih kesulitan untuk menuangkan ide-idenya dalam bentuk tulisan, 2) siswa masih kurang cakap dalam merangkai kata menjadi kalimat yang utuh, 3) siswa masih kurang dalam penggunaan tanda baca dan penetapan huruf kapital, 4) siswa kurang minat membaca, sehingga daya imajinasi siswa dalam menulis cerita fantasi sangat terbatas, 5) siswa masih kurang mampu untuk mengidentifikasi unsur cerita fantasi, 6) siswa masih kesulitan untuk menulis dan menyajikan teks cerita fantasi.

Oleh karena itu, peneliti mencoba meneliti yang berjudul "Upaya Meningkatkan Kemampuan Menulis Teks Cerita Fantasi dengan Menggunakan Metode Picture and Picture Siswa Kelas VII A SMP Negeri 2 Sindangresmi Tahun Pelajaran
2019/2020". Dengan menggunakan metode pembelajaran picture and picture akan mampu menciptakan suasana kegiatan belajar lebih menarik dan menyenangkan serta siswa berperan aktif dalam proses pembelajaran kegiatan menulis cerita fantasi.

Berdasarkan yang telah dipaparkan, maka rumusan masalah dalam penelitian ini adalah (1) Bagaimana penggunaan metode pembelajaran picture and picture dapat meningkatkan minat siswa kelas VII A SMP Negeri 2 Sindangresmi dalam menulis teks cerita fantasi? (2) Bagaimana penggunaan metode pembelajaran picture and picture dapat meningkatkan keaktifan siswa kelas VII A SMP Negeri 2 Sindangresmi dalam menulis teks cerita fantasi? Bagaimana meningkatkan kemampuan menulis cerita fantasi dengan menggunakan metode picture and picture pada siswa kelas VII A SMP Negeri 2 Sindangresmi?

Sehubungan dengan rumusan masalah yang telah dikemukakan, maka tujuan dari penelitian ini adalah (1) Untuk mengetahui minat belajar menulis teks cerita fantasi menggunakan metode pembelajaran picture and picture pada siswa kelas VII A SMP Negeri 2 Sindangresmi. (2) Untuk mengetahui keaktifan menulis teks cerita fantasi menggunakan metode pembelajaran picture and picture pada siswa VII A SMP Negeri 2 Sindangremi. (3) Untuk mengetahui kemampuan menulis teks cerita fantasi menggunakan metode pembelajaran picture and picture pada siswa VII A SMP Negeri 2 Sindangremi.

Sesuai dengan rumusan masalah dan tujuan penelitian, manfaat penelitian dari segi teoritis dan segi praktis yaitu.

(1) Manfaat Teoritis (a) Bahan kajian dalam meningkatkan hasil pembelajaran menulis teks cerita 
fantasi. (b) Sumbangan wawasan dan pengetahuan mengenai pembelajaran teks cerita fantasi.

(2) Manfaat Praktis diharapkan penelitian ini memberikan manfaat

(a) Bagi siswa Memberi kemudahan bagi siswa dalam menemukan ide tulisan menggunakan metode picture and picture, Menjadikan suasana pembelajaran yang menyenangkan bagi siswa dengan menggunakan metode picture and picture,

dan meningkatkan kemampuaan menulis teks cerita fantasi siswa dengan menggunakan metode picture and picture.

(3) Bagi guru hasil peneltian ini dapat mengatasi kesulitan pembelajaran menulis teks cerita fantasi yang dialami guru dengan menggunakan metode picture and picture,

dan menjadi acuan bagi guru untuk membuat pembelajaran menulis teks cerita fantasi lebih kreatif dan inovatif.

(4) Bagi sekolah hasil penelitian ini diharapkan dapat mengatasi permasalahan pembelajaran yang terjadi dengan permasalahan pembelajaran bahasa Indonesia, Membuat sekolah selalu memberi kesempatan kepada semua guru untuk melakukan inovasi pembelajaran khususnya pembelajaran bahasa Indonesia.

\section{LANDASAN TEORITIK}

\section{Minat}

a. Pengertian minat

Menurut M, Buchori (dalam Darmadi, 2017 : 307 ) minat adalah "Kesadaran seseorang, bahwa suatu objek, seseorang, suatu soal atau situasi mengandung sangkut paut dengan dirinya". Jadi minat harus dipandang sebagai suatu sambutan yang sadar, kalau tidak demikian minat itu tidak memiliki arti sama sekali.
Sedangkan

menurut

Sardiman (dalam Darmadi, 2017 : 307) menyatakan, bahwa "Minat seseorang terhadap suatu objek akan lebih kelihatan apabila objek sasaran bekaitan dengan keinginan dan kebutuhan seseorang yang bersangkutan".

Menurut Slameto (2010 : 54) mengemukakan bahwa "Minat dipengaruhi oleh dua faktor yaitu faktor intern dan faktor ekstern. Yang termasuk faktor intern meliputi faktor jasmaniah, faktor psikologis, dan faktor kelelahan. Sedamgkan faktor ekstern meliputi faktor keluarga, faktor lembaga pendidikan dan faktor masyarakat.

\section{Keaktifan}

a. Pengertian keaktifan

Menurut Sardiman (dalam Sinar, 2018 : 9) "Keaktifan adalah kegiatan yang bersifat fisik maupun mental, yaitu berbuat dan berfikir sebagai suatu rangkaian yang tidak dapat dipisahkan.belajar yang berhasil harus melalui berbagai macam aktifitas, baik aktifitas fisik maupun psikis. Aktivitas fisik adalah siswa giat aktif dengan anggota badan, membuat sesuatu, bermain maupun bekerja. Ia tidak hanya duduk dan mendengarkan, melihat atau pasif. Siswa yang memiliki aktifitas psikis (kejiwaan) adalah jika daya jiwanya bekerja sebanyakbanyaknya atau banyak berfungsi dalam rangka pembelajaran".

Dalam Kamus Besar Bahasa Indonesia aktif berarti giat (bekerja, berusaha). Keaktifan diartikan sebagai hal atau keadan dimana siswa dapat aktif.

\section{Kemampuan}

Dalam Kamus Besar Bahasa Indonesia edisi V (2016) dinyatakan 
bahwa "Kemampuan adalah kesanggupan, kecakapan, kekuatan kita berusaha dengan diri sendiri”. Sementara menurut Omar (dalam Sibarani 2007) mengatakan bahwa "Kemampuan adalah identik dengan keterampilan".

Dari pendapat diatas peneliti dapat menyimpulkan bahwa kemampuan adalah kesanggupan seseorang untuk melakukan sesuatu. kemampuan yang dimaksud dalam hal ini adalah kemampuan menulis cerita fantasi dengan benar dan jelas sesuai gambar yang telah ditempelkan oleh guru.

\section{Hakikat Menulis}

a. Pengertian menulis

Menulis merupakan suatu kegiatan komunikasi berupa penyampaian pesan (informasi) secara tertulis kepada pihak lain dengan menggunakan bahasa tulis sebagai alat atau medianya.

Menulis merupakan sebuah proses kreatif menuangkan gagasan dalam bentuk bahasa tulis dalam tujuan, misalnya memberitahu, meyakinkan, atau menghibur.

Menurut Suparno dan Yunus (dalam Dalman, 2018 : 4) menulis "Merupakan suatu kegiatan penyampaian pesan (komunikasi) dengan menggunakan bahasa tulis sebagai alat atau medianya".

Sedangkan menurut Tarigan (dalam Dalman, 2018 : 4) mengemukakan bahwa "Menulis adalah menurunkan atau melukiskan lambang-lambang grafis menghasilkan suatu bahasa yang di pahami oleh seseorang sehingga orang lain dapat membaca lambang-lambang grafis tersebut dan dapat memahami bahasa dan grafis itu".
Kemudian menurut Marwoto (dalam Dalman, 2018 : 4) menjelaskan bahwa "Menulis adalah mengungkapkan ide atau gagasan dalam bentuk karangan secara leluasa. Dalam hal ini, menulis itu membutuhkan skemata yang luas sehingga si penulis mampu menuangkan ide, gagasan, pendapatnya dengan mudah dan lancar"

Berdasarkan pengertian menulis diatas, maka dapat disimpulkan bahwa menulis adalah proses penyampaian pikiran, angan-angan, perasaan, dalam bentuk lambang atau tanda atau tulisan yang bermakna.

b. Tujuan menulis

Menurut Hugo Hartig (dalam Munirah, 2015 : 6) merangkum tujuan menulis sebagai berikut :

1) Tujuan penugasan. Pada tujuan ini, sebenarnya penulis menulis sesuatu karena ditugasi. Misalnya ditugasi merangkum, membuat laporan dan sebagainya.

2) Tujuan altruistik. Penulis bertujuan menyenangkan, ingin menolong para pembaca memahami, menghargai perasaan, ingin membuat hidup para pembaca lebih mudah dan menyenangkan.

3) Tujuan persuasif. Penulis bertujuan meyakinkan para pembaca akan kebenaran yang diutarakan.

4) Tujuan penerangan. Penulis bertujuan memberikan informasi atau keterangan penerangan pada pembaca.

5) Tujuan pernyataan diri. Penulis bertujuan memperkenalkan atau menyatakan diri kepada 
pembaca melalui tulisannya, pembaca dapat memahami sang penulis.

6) Tujuan kreatif. Penulis bertujuan agar para pembaca dapat memiliki nilai artistik atau nilai kesenian. Penulis tidak hanya memberikan informasi, tetapi pembaca terharu tentang hal yang dibacanya.

7) Tujuan pemecahan masalah. Dalam tulisan ini, penulis berusaha memecahkan suatu masalah yang dihadapi. Penulis berusaha memberikan kejelasan kepada para pembaca tentang cara pemecahaan suatu masalah.

Sedangkan menurut Yunus (2015 : 26-27) dalam bukunya ada beberapa tujuan menulis yang dapat dijadikan acuan, antara lain sebagai berikut :

1) Menceritakan sesuatu.

2) Menginformasikan sesuatu.

3) Membujuk pembaca.

4) Mendidik pembaca.

5) Menghibur pembaca.

6) Memotivasi pembaca.

7) Mengekspresikan perasaan dan emosi.

Berdasarkan tujuan menulis diatas, peneliti menyimpulkan bahwa tujuan menulis adalah hal yang sangat komplek karena selain itu harus mengemukakan gagasan atau ide dengan jelas, juga harus menerapkan kaidah bahasa tulis dengan tepat. Kaidah bahasa tulis yang dimaksud adalah dapat menata organisasi karangan menggunakan ejaan. Semua aspek tersebut diperlukan didalam kegiatan tulis menulis dengan berbagai tujuan.

c. Unsur-unsur menulis
1) Gagasan

Gagasan adalah ide, opini, pengalaman atau pengetahuan yang diungkapkan oleh penulis.

2) Ekspresi

Ekspresi adalah pengungkapan gagasan yang dilakukan sedemikian rupa sehingga dapat dipahami dengan baik oleh pembaca.

3) Tatanan

Tatanan adalah aturan atau tata tertib pengembangan dan penyusunan gagasan yang biasa dipedomani penulis.

4) Saran

Saran adalah alat untuk menyampaikan gagasan, yaitu bahasa tulis yang terutama menyangkut kosa kata, tata bahasa, cara menggunakan bahasa yang efektif dan ejaan.

d. Manfaat menulis

Kegiatan menulis memiliki banyak manfaat. Menurut (Dalman, 2018 : 6) manfaat menulis yaitu:

1) Meningkatkan kecerdasan.

2) Mengembangkan daya inisiatif dan kreativitas.

3) Menumbuhkan keberanian, dan

4) Mendorong kemauan dan kemampuan mengumpulkan informasi.

e. Jenis-jenis menulis

Berdasarkan sifat dan teknik penyajiannya, dikenal empat jenis menulis yaitu :
1) Eksposisi (paparan)
2) Deskripsi atau lukisan
3) Argumentasi
4) Narasi atau kisahan

f. Hambatan dalam menulis

1) Terlalu banyak pikiran

2) Bingung mulainya dari mana

3) Tersangkut di paragraf awal

4) Langkah yang tidak mendukung 


\section{Cerita fantasi}

a. Pengertian cerita fantasi

Cerita fantasi adalah cerita fiksi bergenre fantasi yang memaparkan terjadinya peristiwa, dalam bentuk cerita yang bukan sebenarnya terjadi melainkan peristiwa yang diciptakan penulis. (Harsiati, Titik dkk, 2016 : 50).

b. Ciri cerita fantasi

Menurut (harsiati, titik dkk 2016 : 50-51) Cerita fantasi memiliki ciri antara lain:

1) Ada keajaiban atau keanehan atau kemisteriusan.

2) Ide cerita

3) Menggunakan berbagai latar (lintas ruang dan waktu)

4) Tokoh unik (memiliki kesaktian)

5) Bersifat fiksi

6) Bahasa

c. Jenis cerita fantasi

Menurut (Harsiati, Titik dkk, 2016 : 53 - 54) Jenis cerita fantasi diklasifikasikan menjadi dua yaitu, cerita fantasi berdasarkan kesesuaiannya dalam kehidupan nyata, dan cerita fantasi berdasarkan latar cerita.

1) Jenis cerita fantasi berdasarkan kesesuaiannya dalam kehidupan nyata ada dua katagori yaitu.

a) Cerita fantasi total

b) Cerita fantasi irisan

2) Jenis cerita fantasi berdasarkan latar cerita ada dua katagori yaitu.
a) Latar sezaman
b) Latar lintas waktu

d. Langkah-langkah menulis cerita fantasi

1) Merencanakan

a) Menemukan ide penulisan.

b) Berfantasilah dengan bebas.

c) Tulislah tema yang akan kamu tulis. d) Tentukan latar.

e) Tulislah deskripsi tokohtokoh dalam cerita fantasi.

f) Buat sinopsis/ringkasa cerita yang merupakan ringkasan kejadian dari awal sampai akhir.

2) Mengembangkan produk.

3) Memberi judul yang menarik

\section{Metode Pembelajaran Picture And} Picture

a. Pengertian metode picture and picture

1) Metode

Metode pembelajaran adalah rencana menyeluruh mengenai perbuatan belajar mengajar yang serasi sebagai pencapaian tujuan pengajaran.

2) Metode picture and picture

Metode pembelajaran picture and picture ini merupakan salah satu bentuk model pembelajaran kooperatif. Metode pembelajaran kooperatif merupakan suatu model pembelajaran yang mengutamakan adanya kelompok-kelompok.

Pembelajaran kooperatif adalah pembelajaran yang secara sadar dan sistematis mengembangkan interaksi yang saling asah, silih asih, dan silih asuh. Metode pembelajran picture and picture adalah suatu metode belajar yang menggunakan gambar yang dipasangkan atau diurutkan menjadi urutan logis. Pembelajaran ini memiliki ciri aktif, inovatif, kreatif, dan menyenangkan. Model apa pun yang digunakan selalu menekankan aktifnya peserta didik dalam setiap proses pembelajaran. Inovatif, setiap pembelajaran harus memberikan sesuatu yang baru, 
berbeda dan selalu menarik minat peserta didik. Pembelajaran kreatif, setiap pembelajarannya harus menimbulkan minat kepada peserta didik untuk menghasilkan sesuatu atau dapat menyelesaikan suatu masalah dengan menggunakan metode, teknik atau cara yang dikuasai oleh siswa itu sendiri yang diperoleh dari proses pembelajaran.

Metode pembelajaran picture and picture merupakan sebuah metode pembelajaran dimana guru menggunakan alat bantu atau media gambar untuk menerangkan sebuah materi atau memfasilitasi siswa untuk aktif belajar. Dengan menggunakan alat bantu atau media gambar, diharapkan siswa mampu mengikuti pembelajaran dengan fokus yang baik dan dalam kondisi yang menyenangkan, sehingga apa pun pesan yang disampaikan, bias diterima dengan baik dan mampu meresap dalam hati,serta dapat diingat kembali oleh siswa.

b. Prinsip-perinsip pembelajaran metode picture and picture

Menurut Trianto (2010 : 7) ada tujuh prinsip pokok dalam pembelajaran metode picture and picture antara lain :

1) Setiap siswa dibagi beberapa kelompok.

2) Setiap siswa bertanggung jawab atas segala sesuatu yang dikerjakan dalam kelompoknya.

3) Setiap siswa harus mengetahui bahwa semua anggota kelompok mempunyai tujuan yang sama.
4) Setiap siswa harus membagi tugas dan tanggung jawab yang sama diantara anggota kelompoknya.

5) Setiap siswa akan dikenai evaluasi.

6) Setiap siswa berbagi kepeminpinan dan kebutuhan keterampilan interaksi untuk belajar bersama selama proses belajarnya.

7) Setiap siswa akan diminta pertanggung jawaban secara individual materi yang ditangani kelompok interaktif.

c. Kelebihan dan kelemahan menggunakan metode pembelajaran picture and picture

1) Kelebihan pembelajaran dengan metode picture and picture

a) Materi yang diajarkan lebih terarah karena pada awal pembelajaran guru menjelaskan kompetensi yang harus dicapai dan materi secara singkat terlebih dahulu.

b) Siswa lebih cepat menangkap materi ajar karena guru menunjukan gambar-gambar mengenai materi yang dipelajari.

c) Dapat meningkat daya nalar atau daya pikir siswa karena siswa disuruh guru untuk menganalisis gambar yang ada.

d) Dapat meningkatkan tanggung jawab siswa, sebab guru menanyakan alasan siswa mengurutkan gambar.

e) Pembelajarn lebih berkesan, sebab siswa dapat mengamati langsung gambar yang telah dipersiapkan oleh guru. 
2) Kelemahan pembelajaran dengan metode picture and picture

a) Sulit menemukan gambargambar yang sesuai dengan daya nalar atau kompetensi siswa yang dimiliki.

b) Baik guru ataupun siswa kurang terbiasa dalam menggunakan gambar sebagai bahan utama dalam membahas suatu materi pembelajaran.

c) Tidak tersedianya dana khusus untuk menemukan atau mengadakan gambargambar yang diinginkan.

\section{Langkah-Langkah Menulis Cerita} Fantasi Menggunakan Metode Pembelajaran Picture And Picture.

Seorang guru diharuskan menentukan media, materi dan langkah-langkah pembelajaran sebelum memulai kegiatan belajar mengajar. Sehingga dalam proses belajar mengajar, langkah-langkah kegiatan belajar sangat penting untuk disusun sebelum memulai pembelajaran. Langah-langkah menulis cerita fantasi menggunakan metode pembelajaran picture and picture antara lain:

a. Guru melakukan apersepsi

Pada tahap ini guru dan siswa mulai dengan berdo'a bersama, setelah itu siswa memberi salam kepada guru, lalu guru menyampaikan tujuan pembelajaran sesuai KD 4.4 menyajikan gagasan kreatif dalam bentuk cerita fantasi secara lisan dan tulis, dan siswa menerima pengarahan dari guru.

b. Guru menyampaikan materi menulis cerita fantasi menggunakan metode picture and picture.
Pada tahap ini guru mulai melaksanakan proses kegiatan pembelajaran menulis cerita fantasi menggunakan metode picture and picture.

1) Pendahuluan

Pendahuluan merupakan kegiatan awal yang harus dilakukan oleh seorang guru, biasanya guru bertanya hal-hal yang berhubungan dengan cerita fantasi, ciri cerita fantasi, dan jenis cerita fantasi, hal ini dilakukan sebelum dimulainya pembelajaran, dan hal ini dilakukan untuk mengetahui pemahaman siswa tentang materi cerita fantasi.

2) Inti

a) Mengamati
Pada $\begin{array}{r}\text { tahap } \\ \text { mengamati, siswa diberi } \\ \text { sebuah gambar berseri } \\ \text { dengan topik tokoh para } \\ \text { pahlawan, }\end{array}$ membayangkan seakan-akan mereka hidup di zaman tersebut, dengan memperhatikan struktur cerita fantasi yang meliputi orientasi, komplikasi, dan resolusi.

b) Mempertanyakan

Siswa akan bertanya jika ada materi atau hal yang belum dipahami.

c) Menalar

Pada tahap ini, siswa mampu mengembangkan cerita dari hasil pengamatan gambar.

d) Mengasosiasi

Tahap mengasosiasi, siswa secara individu diminta oleh guru untuk membuat cerita fantasi dengan memperhatikan ciri 
dan jenis cerita fantasi yang telah ditemukan pada tahap menalar. Pada tahap ini siswa sudah menggunakan metode pembelajaran picture and picture untuk menulis sebuah cerita fantasi.

e) Mengkomunikasikan

Siswa menyampaikan hasil diskusi didepan kelas, setelah itu siswa lain memberikan tanggapan, baik berupa pertanyaan, tanggapan, atau dukungan.

3) Penutup

Pada tahap ini siswa dan guru membuat simpulan dari pembelajaran cerita fantasi yang telah dilaksanakan. Guru mereviuw bagian mana yang harus dijelaskan lebih lanjut.

\section{B. METODE PENELITIAN}

Penelitian ini dilaksanakan pada semester I tahun pelajaran 2019/2020. Waktu dapat disesuaikan dengan kalender pendidikan di SMP Negeri 2 Sindangresmi. Penelitian tindakan kelas ini dilaksanakan di SMP Negeri 2 Sindangresmi dalam kegiatan penerapan metode pembelajaran picture and picture.

Subjek penelitian ini adalah siswa kelas VII A dengan jumlah 30 siswa, dengan pertimbangan bahwa kelas tersebut para peserta didiknya mengalami kesulitan dalam mata pelajaran Bahasa Indonesia materi cerita fantasi pada Kompetensi Dasar menyajikan gagasan kreatif dalam bentuk cerita fantasi secara lisan dan tulis dengan memperhatikan struktur dan penggunaan bahasa. Selain itu, kelas tersebut tingkat minat serta partisipasinya dalam proses pembelajaran pada mata pelajaran tersebut tergolong rendah (belum memuaskan).

Penelitian ini tergolong penelitian tindakan kelas (PTK). Pada hakikatnya PTK merupakan perbaikan terhadap proses pembelajaran baik proses maupun hasil, yang melakukan PTK di kelas untuk meningkatkan kualitas pembelajaran. Menurut Suharsimi Arikunto (2014) penelitian tindakan kelas merupakan kegiatan penelitian yang dilakukan terhadap sejumlah subjek yang menjadi sasaran adalah peserta didik, bertujuan memperbaiki situansi pembelajaran di kelas agar terjadi peningkatan kualitas pembelajaran.

Adapun prosedur penelitian tindakan kelas ini menggunakan model yang dikembangkan oleh Kurt Lewin. Kurt Lewin menyatakan bahwa penelitian tindakan kelas terdapat beberapa siklus terdiri atas empat langkah yaitu : perencanaan, aksi atau tindakan, observasi, dan refleksi. Yang tampak pada gambar dibawah ini :

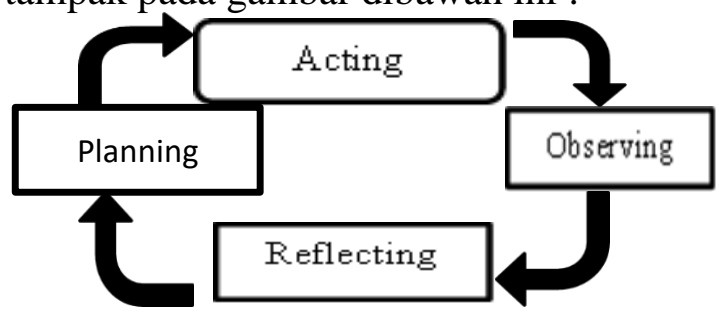

\section{Gambar 1 Model Penelitian Tindakan Kelas Kurt Lewin}

Untuk menerapkan prosedur tersebut diperlukan langkah-langkah berikut (1) Perencanaan (Planing) pada tahap ini peneliti mempersiapkan berbagai perangkat administrasi Kegiatan Belajar-Mengajar (KBM) yang diperlukan pada saat penelitian dilaksanakan, diantaranya adalah :(a) Menentukan standar kompetensi dan kompetensi dasar, menjabarkannya ke dalam bentuk tujuan pembelajaran beserta indikator-indikatornya.(b) 
Mendisain sknario pembelajaran pada siklus pertama dan siklus kedua.(c) Menyusun atau mendisain alat tes yang disesuaikan dengan kompetensi dasar yang akan dikembangkan dan diujikan pada saat prites dan postes.(d) Menyusun instrumen observasi berupa lembar angket siswa yang berisi sejumlah pertanyaan yang dapat dijawab dengan menceklis pada kolom setuju (S), raguragu (RR), dan tidak setuju (TS). (e) Menyusun format observasi aktivitas siswa selama Kegiatan BelajarMengajara (KBM) berlangsung.

Menyiapkan daftar hadir siswa, daftar nilai pretes, dan postes.(f) Menentukan jadwal pembelajaran dimulai dengan kegiatan pretes yang akan dilaksanakan minggu terakhir bulan september tepatnya hari Senin, 30 September 2019. Siklus I pertemuan ke-1; Kamis, 3 Oktober 2019, dan pertemuan ke-2; Senin, 7 Oktober 2019. Selanjutnya siklus II pertemuan ke-1 Senin, 14 Oktober 2019, pertemuan ke-2 Kamis, 17 Oktober 2019. (2) Pelaksanaan Tindakan dilakukan dengan langkahlangkah sebagai berikut. (a) Langkah awal pelaksanaan dimulai dengan melakukan tes pratindakan dengan menggunakan model tes tertulis unjuk kerja menulis cerita fantasi. Tes ini dilakukan sebelum pelaksanaan tindakan dimulai. Tujuannya adalah untuk mengetahui kemampuan awal peserta didik. Hasil tes pratindakan atau pretes selanjtnya akan dibandingkan dengan hasil tes (postes) siklus pertama dan hasil tes (postes) siklus kedua;

(b) Siklus I dilaksanakan sebanyak dua kali pertemuan. Pertemuan pertama berupa penyampaian materi pembelajaran teks cerita fantasi yang selanjutnya disusul pertemuan kedua dengan melaksanakan tes kemampuan menulis cerita fantasi.

(c) Mengidentifikasi kelebihan dan kekurangan (kekuatan dan kelemahan) proses serta hasil proses kegiatan pembelajaran pada siklus I. Hasil identifikasi ini digunakan untuk merencanakan pembelajaran pada siklus II.

(d) Siklus II dilaksanakan sebanyak dua kali pertemuan. Pertemuan pertama, penyampaian materi dan pertemuan kedua pelaksanaan tes. Penyampaian materi melalui proses kegiatan pembelajaran pada siklus II ini diupayakan untuk mencapai target-target yang belum terpenuhi pada siklus I. (3) Observasi dilaksanakan selama pembelajaran berlangsung dengan menggunakan pedoman observasi sebagai alat pengamatan yang berisikan indikator-indikator yang dirancang berdasarkan fokus penelitian, meliputi minat, keaktifan atau partisipasi peserta didik dalam mengikuti proses pembelajaran, dan tingkat pencapaian hasil belajar atau pemahaman peserta didik terhadap materi pelajaran. Observasi juga diperkuat dengan menggunakan catatan lapangan atau jurnal harian untuk merekam data-data hasil temuan yang terjadi secara spontan dan tak terencanakan selama kegiatan berlangsung. (b) Selama observasi peneliti akan dibantu oleh seorang guru mata pelajaran bahasa Indonesia. peneliti bersama guru mata pelajaran Bahasa Indonesia saling bekerjasama dengan tugas mencermati dan mencatat setiap peristiwa yang terjadi. Hasil pencermatan dari kolaborator nantinya akan digunakan sebagai bahan masukan untuk perbaikan pada perencanaan maupun pelaksanaan siklus berikutnya. (c) Di samping instrumen-instrumen yang digunakan di atas, peneliti juga memanfaatkan alat bantu lain berupa kamera untuk mendokumentasikan kegiatan-kegiatan proses pembelajaran di dalam kelas pada saat penelitian berlangsung demi menambah validitas data yang diperoleh. 
(4) Refleksi (a) Menganalisis seberapa jauh telah terjadi perubahan perilaku pada diri siswa setelah dilaksanakan tindakan.

(b) Peneliti bersama guru mata pelajaran bahasa Indonesia mengkaji tingkat keberhasilan dan kegagalan atau kekuatan dan kelemahan yang terjadi pada siklus pertama sebagai bahan masukan untuk menentukan langkahlangkah pada pelasanaan siklus berikutnya.

Jenis data dalam penelitian ini berupa data kualitatif dan data kuantitatif. Menurut Sugiyono (2014 : 3) menjelaskan data kualitatif adalah data yang tidak menggunakan angka. Data kuantitatif adalah data yang mnggunakan angka. Jadi dalam penelitian ini, data kualitatif diperoleh dari hasil kuesioner minat menulis siswa, dan hasil observasi aktivitas siswa dalam proses belajar. Sedangkan, data kuantitatif diperoleh dari hasil pembelajaran menulis cerita fantasi.

Sumber data dalam penelitian ini adalah data kualitatif diperoleh dari hasil kuesioner minat menulis siswa, dan observasi aktivitas siswa. Sedangkan data kuantitatif diperoleh dari hasil kemampuan menulis cerita fantasi.

Metode yang digunakan peneliti untuk mengumpulkan data dalam penelitian ini yaitu :(a) Angket atau kueisioner (b) Observasi (c) Tes (d) Dokumentasi (e) Buku Referensi.

Instrument penelitian ini, datadata diambil dengan menggunakan 3 instrumen yaitu : (a) Instrument angket minat menulis siswa. (b) Lembar observasi aktivitas siswa. (c) Lembar penilaian kemampuan menulis cerita fantasi.

\section{HASIL PENELITIAN DAN PEMBAHASAN}

Pelaksanaan penelitian ini tindakan kelas ini didasarkan pada tes siklus I dan siklus II. Pembahsaan hasil tersebut meliputi hasil tes dan nontes. Pembahasan hasil tes penelitian mengacu pada pemerolehan nilai yang dicapai siswa ketika menulis cerita fantasi. Pembahasan hasil nontes meliputi observasi aktivitas siswa, angket minat menulis siswa dan dokumentasi foto.

Sebelum dilaksanakan penelitian tindakan kelas, peneliti melakukan observasi dan pengamatan terhadap hasil kemampuan menulis cerita fantasi. Evaluasi menlis cerita fantasi pada tahap prasiklus menunjukan bahwa hasilnya masih rendah nilai rata-rata siswa yaitu 60,23 . Hal ini disebabkan karena dalam mengajar guru hanya memberikan ceramah dan belum menggunakan model pembelajaran yang tepat.

Penelitian ini mencoba menerapkan penggunaan metode picture and picture pada pembelajaran kemampuan menulis cerita fantasi. Melalui model pembelajaran guru dapat membantu peserta didik mendapatkan informasi, ide, keterampilan, cara berfikir, dan mengekspresikan ide. Penerapan metode picture and picture yang didukung dengan media gambar seri yang dipasangkan atau diurutkan menjadi urutan logis. Gambar yang digunakan disesuaikan dengan materi, kondisi dan karakteristik siswa.

Metode picture and picture adalah suatu model belajar yang menggunakan gambar dan dipasangkan atau diurutkan menjadi urutan logis. Model pembelajaran ini mengandalkan gambar sebagai media dalam proses pembelajaran. Gambar-gambar ini menjadi faktor utama dalam proses pembelajaran. Gambar seri tersebut digunakan untuk mempermudah siswa dalam menentukan aspek-aspek yang dinilai dalam pembelajaran menulis cerita fantasi meliputi lima aspek, yaitu kesesuaian isi cerita dengan tema, 
struktur meliputi (orientasi, komplikasi dan resolusi), kreativitas pengembangan cerita, penggunaan huruf besar dan tanda baca, amanat atau moral (tersurat atau tersirat) sehingga menjadi cerita fantasi.

Perolehan hasil tes peningkatan kemampuan menulis cerita fantasi pada siklus I dan siklus II kelas VII A SMP Negeri 2 Sindangresmi dapat dilihat pada tabel 1 berikut.

\section{Tabel 1 perbandingan hasil tes menulis cerita fantasi siklus I dan siklus II.}

\begin{tabular}{|c|c|c|c|c|c|c|c|}
\hline \multirow[b]{2}{*}{ no } & \multirow[b]{2}{*}{ katagori } & \multicolumn{2}{|c|}{ prasiklus } & \multicolumn{2}{|c|}{ siklus I } & \multicolumn{2}{|c|}{ siklus II } \\
\hline & & $\begin{array}{c}\text { jumlah } \\
\text { nilai }\end{array}$ & $\begin{array}{l}\text { nilai rata- } \\
\text { rata }\end{array}$ & $\begin{array}{c}\text { jumlah } \\
\text { nilai }\end{array}$ & $\begin{array}{c}\text { nilai } \\
\text { rata- } \\
\text { rata }\end{array}$ & $\begin{array}{c}\text { jumlah } \\
\text { nilai }\end{array}$ & $\begin{array}{c}\text { nilai rata } \\
\text { rata }\end{array}$ \\
\hline 1 & sangat baik & & $\underline{1807}$ & 170 & 2145 & 1425 & 2490 \\
\hline 2 & baik & 580 & 30 & 1340 & 30 & 1065 & 30 \\
\hline 3 & cukup & 560 & $=60,23$ & 635 & $=71,5$ & 0 & $=83$ \\
\hline 4 & kurang & 625 & & 0 & & 0 & \\
\hline 5 & sangat kurang & 42 & & 0 & & 0 & \\
\hline & JUMLAH & 1807 & & 2145 & & 2490 & \\
\hline & KATAGERI & Cukup & & Baik & & Baik & \\
\hline
\end{tabular}

Berdasarkan tabel 1 dapat dijelaskan bahwa ketuntasan dari hasil rata-rata nilai siswa untuk kompetensi kemampuan menulis cerita fantasi siswa dari siklus I sampai siklus II mengalami peningkatan. Uraian tabel diatas, dapat dijelaskan secara rinci sebagai berikut.

Pada tes prasiklus nilai rata-rata siswa 60,23 termasuk dalam katagori cukup (rentang nilai 60-69). Peningkatan dari prasiklus ke siklus I sebesar 11,27. Pada siklus II mengalami peningkatan sebesar 11,5 dari hasil siklus I.

Setelah pelaksanaan tes menulis cerita fantasi pada prasiklus dengan nilai rata-rata 60,23 atau dalam katagori cukup. Pada siklus I dengan nilai ratarata 71,5 atau dalam katagori baik. Prasiklus masih belum mencapai nilai rata-rata batas minimal yaitu 75 , sedangkan pada siklus I dan siklus II sudah banyak yang mencapai nilai ratarata batas minimal yaitu 75 , sehingga hasil tersebut sudah mengalami peningkatan.

Berdasarkan hasil yang diperoleh pada tiap siklus di atas, maka dapat diketahui bahwa terjadi peningkatan kemampuan menulis cerita fantasi pada siswa kelas VII A SMP Negeri 2 Sindangresmi setelah dilakukan pembelajaran menulis cerita fantasi menggunakan metode picture and picture.

Perbandingan hasil observasi aktivitas siswa siklus I dan siklus II dijabarkan pada tabel berikut ini.

\section{Tabel 2 Perbandingan Hasil Observasi Aktivitas Siswa Siklus I Dan Siklus II}

\begin{tabular}{|c|c|c|c|c|}
\hline No & Aktivitas KBM & Siklus I & $\begin{array}{l}\text { Siklus II } \\
\%\end{array}$ & Peningkatan \\
\hline 1 & Kehadiran siswa & 100 & 100 & 0 \\
\hline 2 & $\begin{array}{|lr|}\text { Perhatian } & \text { siswa } \\
\text { pada } & \text { saat } \\
\text { membuka } & \\
\text { pelajaran } & \\
\end{array}$ & 73,33 & 100 & 26,67 \\
\hline 3 & $\begin{array}{l}\text { Kesiapan siswa } \\
\text { untuk mengikut } \\
\text { seluruh rangkaian } \\
\text { KBM }\end{array}$ & 70 & 96,67 & 26,67 \\
\hline 4 & $\begin{array}{|lr|}\text { Jumlah } & \text { siswa } \\
\text { yang fokus pada } \\
\text { pokok } & \text { bahasan } \\
\text { yang } & \text { sedang } \\
\text { dipelajari } & \end{array}$ & 76,67 & 90 & 13,33 \\
\hline 5 & $\begin{array}{|lr|}\text { Jumlah } & \text { siswa } \\
\text { yang } & \text { mencata } \\
\text { hal-hal } & \text { penting } \\
\text { dari } & \text { penjelasan } \\
\text { guru } & \end{array}$ & 83,33 & 93,33 & 10 \\
\hline 6 & $\begin{array}{l}\text { Jumlah siswa } \\
\text { yang aktif } \\
\text { bertanya, } \\
\text { menjawab, } \\
\text { berkomentar }\end{array}$ & 60 & 83,33 & 23,33 \\
\hline 7 & $\begin{array}{|lr|}\text { Jumlah } & \text { siswal } \\
\text { yang } & \text { cepat } \\
\text { tanggap terhadap } \\
\text { permasalahan }\end{array}$ & 56,67 & 80 & 23,33 \\
\hline
\end{tabular}

Berdasrkan tabel 2, pada aspek pertama yaitu kehadiran siswa dalam mengikuti pembelajaran tidak mengalami peningkataan karena pada siklus I dan siklus II seluruh siswa hadir semua.

Aspek yang kedua yaitu perhatian siswa pada saat membuka pelajaran mengalami peningkatan sebesar 26,67\%, siklus I sebesar 73,33\% dan siklus II sebesar $100 \%$. Pada siklus I masih terdapat siswa yang tidak memperhatikan guru ketika membuka pembelajaran dan sebagian siswa masih banyak yang bergurau dengan temannya. Pada siklus II siswa memperhatikan dan fokus pada pembelajran yang diberikan oleh guru.

Aspek yang ketiga yaitu kesiapan siswa untuk mengikuti seluruh rangkaian 
KBM mengalami peningkatan sebesar $26,67 \%$. Pada siklus I sebesar $70 \%$ dan siklus II 96,67\%. Pada siklus I terdapat 21 siswa yang siap mengikuti seluruh rangkaian KBM sedangkan, pada siklus II terdapat 29 siswa yang siap mengikuti seluruh rangkaian KBM

Aspek yang keempat yaitu jumlah siswa yang fokus pada pokok bahasan yang sedang dipelajari mengalami peningkatan sebesar $13,33 \%$. Pada siklus I sebesar 76,67\% dan siklus II sebesar $90 \%$. Sebagian siswa sudah mulai fokus pada pokok bahasan yang sedang dipelajarai.

Aspek yang kelima yaitu jumlah siswa yang mencatat hal-hal penting dari penjelasan guru mengalami peningkatan sebesar 10\%. Pada siklus I sebesar $83,33 \%$ dan pada siklus II sebesar $93,33 \%$. Siswa sudah mulai mencatat hal-hal yang menurut siswa penting.

Aspek yang keenam yaitu jumlah siswa yang aktif : bertanya, menjawab, berkomentar mengalami peningkatan sebesar 23,33\%. Pada siklus I sebesar $60 \%$ dan siklus II 83,33\%. Pada siklus I siswa masih mengalami kesulitan dalam menulis cerita fantasi tetapi mereka aktif bertanya kepada guru mengenai kesulitan yang dihadapi. Pada siklus II, siswa sudah tidak merasa malu ketika bertanya, menjawab dan berkomentar kepada guru. Hal ini disebabkan siswa ingin menulis cerita fantasi dengan baik.

Aspek yang terakhir jumlah siswa yang cepat tanggap terhadap permasalahan atau pertanyaan yang muncul dalam KBM mengalami peningkatan sebesar 23,33\%. Pada siklus I sebesar 56,67\% dan siklus II sebesar $80 \%$. Pada siklus I masih ada sebagian siswa yang masih belum cepat tanggap terhadap permasalahan atau pernyataan yang muncul dalam KBM. Sedangkan pada siklus II siswa sudah mulai cepat tanggap menyelesaikan permasalahan yang muncul dalam KBM.

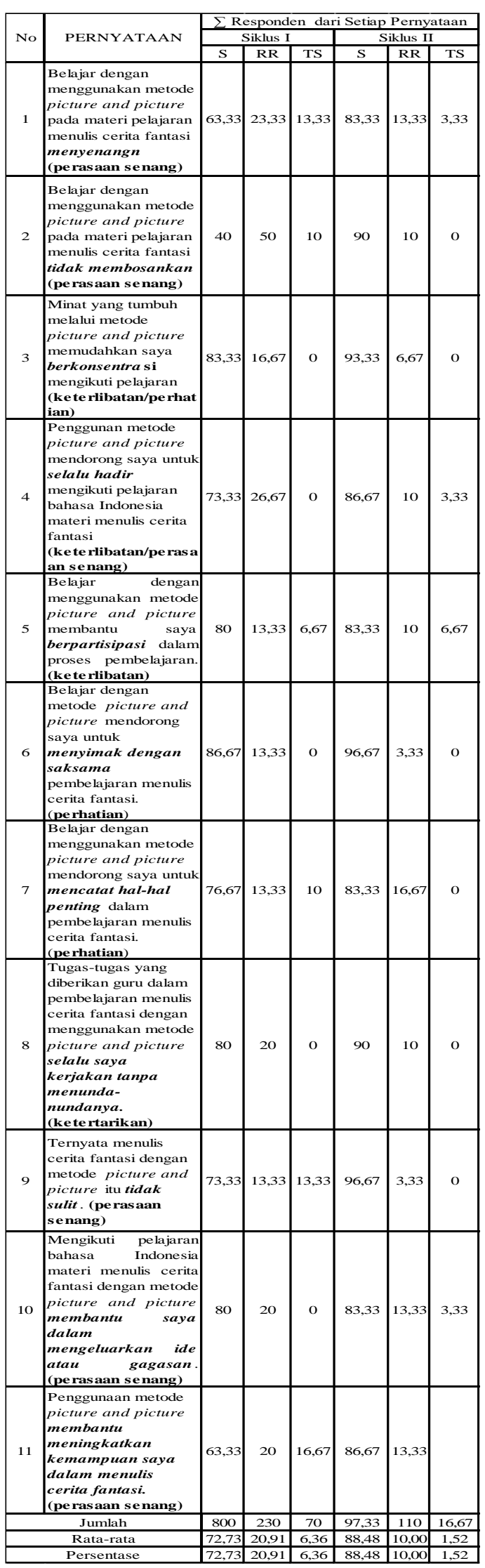

Perbandingan minat siswa terhadap pembelajaran menulis cerita 
fantasi dengan menggunakan metode picture and picture pada siklus I dan siklus II. Dijabarkan pada tabel berikut.

Tabel 3 perbandingan hasil minat siswa pada siklus I dan siklus II.

Tabel 3 menujukan hasil minat siswa mengalami peningkatan terhadap pembelajaran menulis cerita fantasi menggunakan metode picture and picture, pada siklus I nilai rata-rata persentase pada aspek setuju sebesar $72,73 \%$ dan pada siklus II sebesar $88,48 \%$ mengalami peningkatan sebesar $15,75 \%$. Sedangkan nilai rata-rata persentase aspek ragu-ragu pada siklus I sebesar $20,91 \%$ dan pada siklus II sebesar $10,00 \%$ sudah mengalami peningkatan karena pada siklus II sudah mulai berkurang yang memilih raguragu terhadap pembelajaran menulis cerita fantasi menggunakan metode picture and picture. Dan kemudian pada nilai rata-rata persentase pada aspek tidak setuju siklus I sebesar $6,36 \%$ dan siklus II sebesar 1,52\%, mengalami peningkatan karena pada siklus II sudah mulai berkurang siswa yang tidak setuju terhadap pembelajran menulis cerita fantasi menggunakan metode picture and picture. Dengan menggunakan metode picture and picture minat siswa terhadap kemampuan menulis semakin meningkat dan siswa merasa senang, tertarik ketika dikasih tugas oleh guru untuk menulis.

\section{KESIMPULAN DAN SARAN}

Berdasarkan hasil penelitian kemampuan menulis cerita fantasi menggunakan metode picture and picture, dapat disimpulkan sebagai berikut.

(1) Proses kemampuan menulis cerita fantasi menggunakan metode picture and picture pada siswa kelas VII A SMP Negeri 2 Sindangresmi tahun ajaran 2019/2020 mengalami perubahan kearah yang positif. Hal tersebut dapat diketahui dari hasil nontes meliputi observasi aktivitas siswa, angket minat siswa dan dokumentasi pada siklus I dan siklus II. Berdasarkan analisis data hasil nontes pada siklus I, sebagian besar siswa memiliki sikap yang baik, pada siklus I, siswa merasa lebih mudah untuk memahami menulis cerita fantasi. Melalui metode picture and picture, siswa lebih menjadi lebih mudah dan tertarik dalam menulis cerita fantasi. Meskipun demikian masih ada beberapa siswa masih terlihat kurang aktif, kurang bersemangat dan antusias dalam mengikuti pembelajaran. Namun, pada siklus II siswa telah mengalami perubahan kearah yang positif terhadap aktivitas siswa dan minat siswa terhadap menulis cerita fantasi. Hal tarsebut dilihat dari sikap siswa yang antusias, lebih menarik, dan bersemangat dalam mengikuti pembelajaran menulis cerita fantasi. Sebagian besar siswa lebih aktif selama pembelajaran. Siswa juga lebih fokus terhadap pembelajaran.

(2) Kemampuan menulis cerita fantasi siswa kelas VII A SMP Negeri 2 Sindangresmi tahun ajaran 2019/2020 setelah mengikuti pembelajaran menulis cerita fantasi dengan menggunakan metode picture and picture mengalami peningkatan. Pada prasiklus diperoleh nilai rata-rata sebesar 60,23 termasuk dalam katagori cukup. Hasil siklus I diperoleh nilai rata-rata kelas sebesar 71,5 termasuk dalam katagori baik, pada siklus II, diperoleh nilai rata-rata kelas sebesar 83 termasuk dalam katagori baik. Dengan demikian, terjadi peningkatan nilai rata-rata dari sikuls I ke siklus II sebesar 11,5. Hal ini menunjukan bahwa setelah dilakukan pembelajaran menulis cerita fantasi dengan menggunakan metode picture and picture. Kemampuan siswa menulis cerita fantasi meningkat.

Berdasarkan hasil penelitian mengenai kemampuan menulis cerita fantasi dengan menggunakan metode 
picture and picture pada siswa kelas VII A SMP Negeri 2 Sindangresmi tahun ajaran 2019/2020, berikut merupakan beberapa saran yang telah penulis rangkum.

(1) Bagi siswa diharapkan dapat menanamkan atau menguasai aspek keterampilan berbahasa, yaitu menyimak, membaca, berbicara, dan menulis. Hal ini dilakukan agar siswa terbiasa memahami atau berargumen pada saat kegiatan belajar maupun di luar kegiatan belajar.

(2) Bagi guru model pembelajaran sangat berpengaruh saat kegiatan pembelajaran di kelas. Untuk mencapainya keberhasilan pembelajaran siswa, seorang guru harus menggunakan model pembelajaran yang variatif agar saat kegiatan belajar siswa tidak lagi merasa jenuh dan bersemangat melalui pembelajaran yang digunakan.

(3) Bagi sekolah melalui modelmodel pembelajran yang digunakan oleh guru tidak hanya menyampaikan materi saja, melainkan untuk meningkatkan kemampuan siswa dalam proses pembelajaran. Melalui guru yang kompenten dalam hal mengajardan mendidik dapat meningkatkan mutu sekolah. (4) Bagi para peneliti lain yang menekuni bidang penelitian bahasa dan sastra Indonesia hendaknya dapat melakukan penelitian lanjutan mengenai kemampuan menulis cerita fantasi.

\section{DAFTAR PUSTAKA}

Arikunto, Suharsimi. 2014. Prosedur Penelitian Suatu Pendekatan Praktek. Jakarta : PT. Rineka Cipta.

Dalman. 2018. Keterampilan Menulis. Jakarta : Rajawali Pers.

Darmadi. 2017. Pengembangan Model Dan Metode Pembelajaran Dalam Dinamika Belajar Siswa. Yogyakarta : Deepublish.

Hamdayana, Jumanta. 2017. Model Dan
Metode Pembelajaran Kreatif Dan Berkarakter. Jakarta : Ghalia Indonesia.

Harsiati, Titik dkk. 2016. Bahasa Indonesia. Jakarta : Pusat Kurikulum dan Kebudayaan.

Kemendikbud. 2016. Kamus Besar Bahasa Indonesia. Jakarta : Balai Pustaka.

Munirah. 2015. Pengembangan Menulis Paragraf. Yogyakarta : Deepublish.

Sibarani. Maria Ruth Febriani. 2017. Jurnal. Pengaruh Penggunaan Media Film "Aisyah Biarkan Kami Bersaudara" Terhadap Kemampuan Menulis Karangan Narasi Oleh Siswa Kelas X SMA NEGERI 11 Medan Tahun Pembelajaran 2016/2017. Universitas Negeri Medan.

Sinar. 2018. Metode Active Learning Upaya Meningkatkan Keaktifan dan Hasil Belajar Siswa. Yogyakarta : Deepublish.

Slameto. 2010. Belajar Dan FaktorFaktor Yang Mempengaruhinya. Jakarta : Rineka Cipta.

Sukardi. 2003. Bimbingan dan Penyuluhan Belajar di Sekolah. Bandung : Usaha Nasional.

Surya, Mohamad. 2004. Psikologi Pembelajaran dan Pengajaran. Bandung : PT Remaja Rosda Karya.

Trianto. 2010. Model Pembelajaran Terpadu. Jakarta : Bumi Aksara.

Widiarti. 2013. Skripsi. Keefektifan model sinektik Dalam Pembelajaran Keterampilan Menulis Cerpen Siswa Kelas X SMA Negeri 2 Purworejo. Universitas Negeri Yogyakarta.

Yunus, Syaripudin. 2015. Menulis Kreatif. Bogor : Ghalia Indonesia. 